\title{
Influence of wood anisotropy on its mechanical properties in relation to the scale effect
}

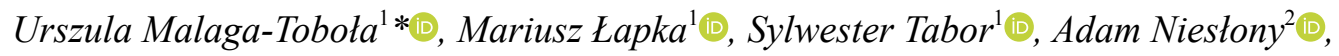 \\ and Pavol Findura ${ }^{3}$ (D) \\ ${ }^{1}$ Institute of Agricultural Engineering and Informatics, University of Agriculture in Kraków, Balicka 116B, 30149 Kraków, Poland \\ ${ }^{2}$ Opole University of Technology, Faculty of Mechanical Engineering, Mikołajczyka 5, 45-271 Opole, Poland \\ ${ }^{3}$ Department of Machines and Production Biosystems, Faculty of Engineering, Slovak University of Agriculture in Nitra, \\ Hlinku 2, 94976 Nitra, Slovakia \\ Received September 14, 2018; accepted February 3, 2019
}

\begin{abstract}
As a construction material wood is characterized by many advantages: low density, a high degree of strength and stiffness, low thermal and electrical conductivity and chemical durability. However, it is an anisotropic material that contains structural elements of varying stiffness and strength. When moisture levels increase, it is characterized by the variability of its mechanical properties and creep resulting from rheological properties. Therefore, it is important to understand how the mechanical properties of wood vary depending on its heterogeneity, the orientation of the sample in relation to the directions of anisotropy and its natural disadvantages. The research material was obtained from the lumber of pine wood, which on the basis of the foursided planing process was divided into 2 groups: A, B. The wood was subjected to strength tests specifying for appropriate groups of samples respectively: modulus of elasticity in static bendinggroup A-B, static bending strength - group A-B. The influence of wood anisotropy on the elasticity and strength properties of wood was demonstrated, this results from the variability of the wood element orientation and load direction in relation to the main directions of anisotropy.
\end{abstract}

Keywords: wood, structure, anisotropy, scale effects, mechanical properties

\section{INTRODUCTION}

With regard to various criteria, wood tends to exceed other building materials. However, some wood properties - which substantially affect the quality of wood products, such as low strength and stiffness in a direction perpendicular to its fibres, considerable variations in mechanical properties following an increase in its moisture content and wood creep as a result of its rheological properties (even at room temperatures) may result in a lack of confidence in wood as a building material. This lack of trust is

*Corresponding author e-mail: umalagatobola@gmail.com mainly due to an insufficient knowledge of the mechanical properties of wood and its products (Moskaleva, 1957; Perełygin, 1957; Mareš and Blahovec, 2004; Stasiak et al., 2018). Many studies have been carried out to elucidate the mechanical properties of different kinds of wood, but most of them concerned the dry woods used in the wood and paper industries (Korkut and Guller, 2008; Lionetto and Frigione, 2009; Niklas, 1997).

One of the most important properties of the material, which is closely associated with its other properties is structure. Studies have shown that, among other effects, the microstructure influences the mechanical resistance of wood tissue and that the microstructure undergoes changes during storage (Aguilera, 2005; Gancarz and Konstankiewicz, 2007).

As with other construction materials, the properties of wood are determined by its structure, which is usually investigated at three different levels: macroscopic, microscopic and submicroscopic (Manrique et al., 1994). The microscopy images obtained using many microscopy or macroscopy techniques are used to study the structure of tissues, their changes and anisotropy (Gancarz et al., 2007). This is due to the fact that normal wood structure contains both regular and irregular (non-homogenous) elements as well as wood faults. The structure of wood also determines the anisotropy of wood strength and the elastic-viscousplastic characteristics of wood as a construction material - these issues are the subject matter of a technical science, which aims to elucidate the composition of wood (Kollman, 1967; Sobolev, 1979; Miller, 1999; Thibaut et al., 2001; Mishnaevsky and Qing, 2008; Stasiak et al., 2018).

(C) 2019 Institute of Agrophysics, Polish Academy of Sciences 
One important issue is the influence of the properties of wood structure on its mechanical properties. This issue is closely related to understanding the essence of the scale effect in wood. This issue is central to solving some of the major issues in the technical science concerned with wood properties - the determination of the relationship between the mechanical characteristics of wood and the dimensions of the examined specimens and actual materials used in construction as well as other plant materials (Leontev, 1970; Bodig and Jayne, 1982; Madsen, 1992; Łapka and Sztyber, 2007; Gancarz et al., 2014).

In the article, research concerning the occurrence of a scale effect in the mechanical strength of wood was described. It was pointed out that the problem of the occurrence of the scale effect in the study of anisotropic materials, to which wood belongs, results from the method of preparation of normative samples. The assumptions applied to standards show a similarity to isotropic and anisotropic materials. However, attention should be paid to the fact that anisotropic materials, especially those of organic origin, as a result of the occurrence of natural inhomogeneities in the anatomical structure, represent a group from which it is impossible to clearly determine representative features within size scaled samples. This translates into erroneous strength assumptions, especially in relation to anisotropic construction materials, as a result of the lack of correction factors. The consequence of not including the scale effect in project practice is the problem of oversizing. The use of certain methods leads to false assumptions concerning an increase in strength, and this increases the probability of the occurrence of more undetected defects in this material as a result of the unjustified increase in their volume.
This paper undertakes an attempt to assess the scale effect in an ad hoc test of pine wood properties. The research involved basic testing aimed at determining strength properties: the determination of static bending strength and the calculation of the elasticity modulus during static bending. The objective was realized on the basis of analysing the following parameters:

- wood non-homogeneous qualities,

- orientation of a specimen with respect to the direction of wood anisotropy,

- natural wood faults (mainly gnarliness).

\section{MATERIAL AND METHODS}

The object of the tests described in this paper is pine wood (Pinus sylvestris) obtained from the forests of 5th Silesia Land, which was grown in areas with similar conditions as characterized by a single soil evaluation class.

As a result of the lumber classification carried out using a visual method, three sorting classes were established from which the wood premium class (KW) was accepted as having the highest utility values for further research. This method was also used in research conducted by Noskowiak et al. $(2013,2014)$.

As a result of the process of four sided planing, two groups of wood specimens were identified: A, B (Fig. 1) -40 specimens in each group, which were subsequently used for a fatigue test. The B group specimens were also fault-free and had a uniform course of annual growth along their cross-section. The influence of wood defects on the value of the modulus of elasticity in wood was the subject of research by Chinese scientists (Zhong et al., 2012).

A

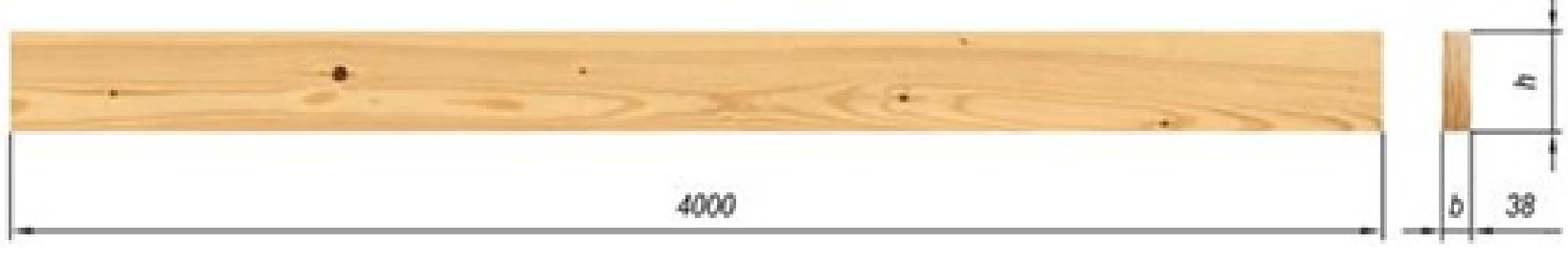

B

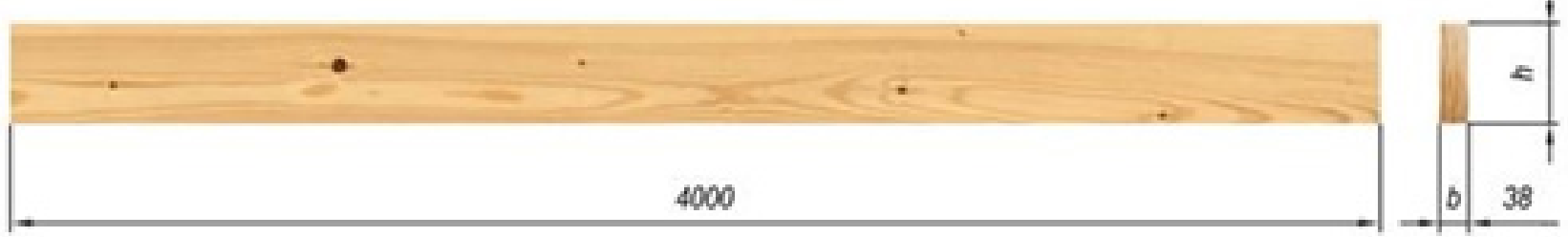

Fig. 1. Dimensions of pine timber in accordance with group speciment: A - PN-EN 408:2004, B - PN-63/D-04117 and PN-77/D-04103 selected for the determination of the modulus of elasticity during static bending and testing static bending strength, where: $\mathrm{b}-\mathrm{cross}-$ section in the radial direction, $\mathrm{h}$ - cross-section in the tangential direction. 


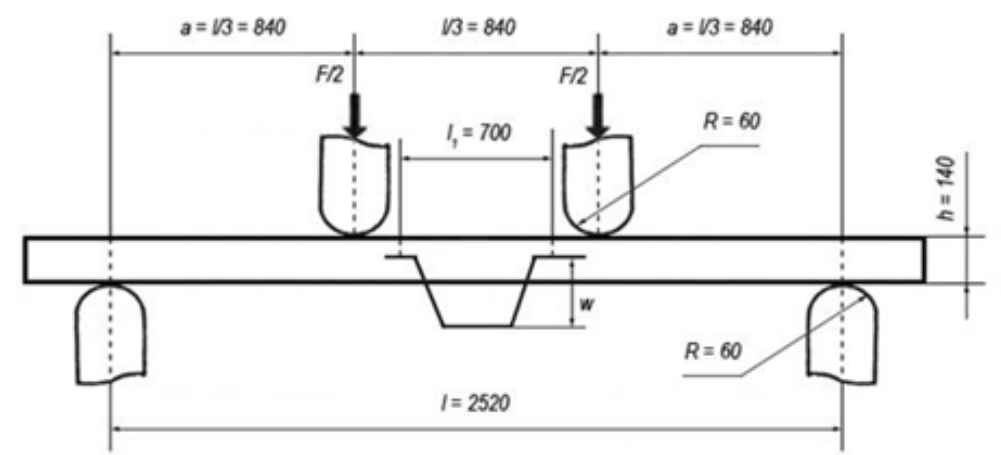

Fig. 2. Diagram illustrating how the load was applied to timber A specimens (four-point loading method) during the calculation of the modulus of elasticity for static bending and static bending strength, where: $a$-distance between the point of force application and nearest support (mm), F/2 - distance between the loads and direction of loading, $h$ - height of the largest side of the timber cross-section $(\mathrm{mm}), w$-displacement, $l$ - specimen span measured between the supports $(\mathrm{mm}), l_{1}$ - specimen length (mm), $R$ - radius of curvature of supports and loads (mm).

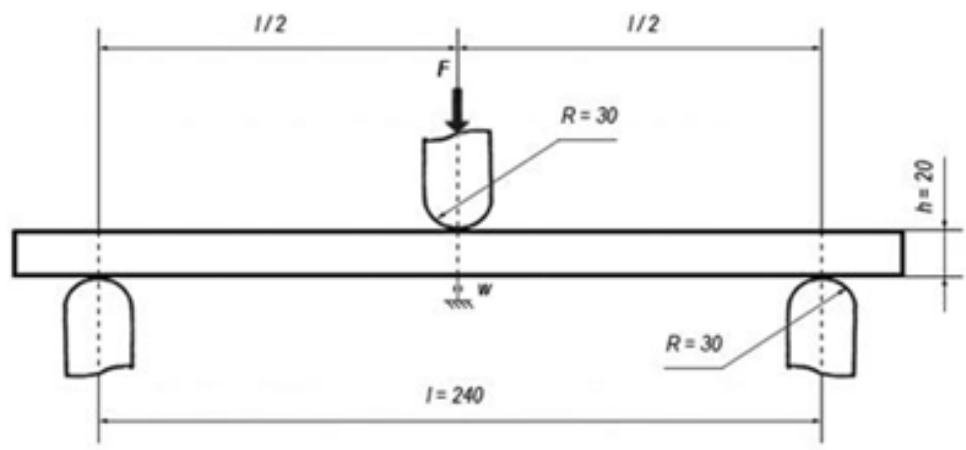

Fig. 3. Diagram of load application to group B specimens (three-point method), during the calculation of the modulus of elasticity during static bending and static bending strength, where: $\mathrm{F}$ - direction of load, $\mathrm{h}$ - height of the largest side of the timber cross-section $(\mathrm{mm}), \mathrm{w}$ - displacement, 1 - specimen span measured between the supports ( $\mathrm{mm}), \mathrm{R}$ - radius of curvature of supports and loads (mm).

Prior to the fatigue tests the wood specimens were conditioned so as to ensure that a moisture content of $12 \pm 3 \%$ was obtained. The moisture content was tested after the completion of the fatigue tests using the dry oven method (PN-EN 13183-1:2004). The proper execution of the drying process allows for the more rapid extraction of water (Sándor et al., 2006; Obataya et al., 2006; Barański et al., 2013). Other benefits are a decrease in the equilibrium moisture content of the wood or greater resistance to degradation (Langrish et al., 1992, 1993; Sun et al., 2000; Pang et al., 2001). The use of an inappropriate method may result in a decrease in its mechanical properties (Wierzbowski et $a l ., 2009)$. The wood density was determined using a stereometric method (PN-77/D-04101). This method consists of measuring the volume of the sample through the determination of various dimensions (length, width, height), and weighing the sample. This method was also used by other specialists in their study (Chuchała et al., 2012; Bieniasz et al., 2017). The pine wood was subjected to fatigue tests on a universal fatigue test stand manufactured by the INSTRON company.

The value of the modulus of elasticity of the specimens in group A was determined by the application of two loads, at two symmetrical points with a span 18 times greater than the height of the cross-section. The distance between the applied loads and between the loads and supports was equal to six heights of the cross-section of the specimen (Fig. 2). The specimens were subjected to loads in the areas of pure bending perpendicular to their surface in the proportionality range of the relationship between the load and deflection (Fig. 3).

During the test the force was applied uniformly to the specimens $(F)$ with a constant velocity of $8 \mathrm{~mm} \mathrm{~min}^{-1}$. Deflection $(w)$ was measured in relation to the neutral axis along both lateral specimen planes, in the central measurement base of a sensor, whose length was equal to five times the height of the cross-section of the tested specimen.

On the basis of the results of research performed on the specimens it was possible to draw up a relationship between the specimen load and its displacement. The relationship which corresponds to the load in the range from $0.1 F_{\max }$ to $0.4 F_{\max }$ was used in the regression analysis. For each chart the longest stretch of this section was identified, as it corresponded to a correlation coefficient equal to at least 0.99 . For the case in which the examined section contained a correlation coefficient at least in the range from $0.2 F_{\max }$ to $0.3 F_{\max }$, the calculations of the modulus of elasticity of the wood specimens in group A were performed through the application of the formula (PN-EN 408:2004): 


$$
E_{m, l(A)}=\frac{\left(F_{2}-F_{1}\right) 0,75 a l_{1}^{2}}{\left(w_{2}-w_{1}\right) b h^{3}},
$$

where: $\left(F_{2}-F_{1}\right)-$ increment of the load corresponding to the section of the regression line with the correlation coefficient equal to at least $0.99 \mathrm{~N}, a$ - distance between the point of force application and the nearest support $(\mathrm{mm})$, $l_{1}$ - length of the specimen $(\mathrm{mm}),\left(w_{2}-w_{1}\right)$ - increment in displacement corresponding to the increase of the load ( $\mathrm{mm}$ ), $b-$ specimen width $(\mathrm{mm}), h-$ specimen height $(\mathrm{mm})$.

The determination of the modulus of elasticity in group B specimens was conducted under the effect of a single lumped force in the perpendicular direction to the axial cross-section of the wood. The specimens were placed on two supports where they could move freely in a manner which enabled the transfer of the load onto the specimen in the middle of its length. The distance between the supports was 12 times greater than the height of the specimen. The distance between the load and the support was equal to six times the height of the specimen (Fig. 3).

Just as in the case of the specimens in group A, a regression analysis was prepared for each section of the chart corresponding to the range of the load from $0.1 F_{\max }$ to $0.4 F_{\max }$.

The calculations of the modulus of elasticity of the wood specimens in group B were performed through the application of the formula (PN-63/D-04117) (Fig. 3):

$$
E_{m, l(B)}=\frac{\left(F_{2}-F_{1}\right) l^{3}}{4\left(w_{2}-w_{1}\right) b h^{3}} .
$$

For comparative purposes applied in the analysis of the results, the value of the modulus of elasticity during static bending in wood specimens of group A and B and moisture content $W\left(E_{m . l}\right)$ were converted into the value of the local modulus of elasticity of the wood during static bending for a moisture content of $12 \%\left(E_{m . l(12)}\right)$. The value of the moisture content in wood specimens was in the range from $9 \%$ $\leq W \leq 15 \%$; therefore, the transformation was performed on the basis of the formula (PN-77/D-04103):

$$
E_{m, l(12)}=E_{m, l}[1+\alpha(W-12)],
$$

where: $E_{m . l}-$ value of the modulus of elasticity during static bending (specimen groups $\mathrm{A}$ and $\mathrm{B}$ ) during the test (MPa), $\alpha$-variation in the value of the coefficient of the modulus of elasticity during static bending as a result of changing its moisture content by $1 \%(\alpha=0.02), W$ - moisture content in a wood specimen during the test using the drying oven method (\%).

The method used for the determination of the static bending strength of group A and B specimens was similar to the case of the determination of the modulus of elasticity. For the case of specimens from group A, the bending applied the four-point method (Fig. 2) while for specimens from group B the method applied a single bending force acting on the specimens (Fig. 3). The determination of the modulus of elasticity and static bending strength occurred simultaneously for each specimen from groups A and B.

The static bending strength of the group A samples with a moisture content $W$ at the time of the test was derived from the formula (PN-EN 408:2004):

$$
\sigma_{m(A)}=\frac{3 a F_{\max }}{b h^{2}},
$$

where: $F_{\max }-$ maximum load (N).

The static bending strength of the specimens from group B with a moisture content $W$ at the time of the test was derived from the formula (PN-77/D-04103):

$$
\sigma_{m(B)}=\frac{3 F_{\max } l}{2 b h^{2}} .
$$

For comparative purposes applied in the analysis of the research results the values of static bending for group A and B wood specimens and moisture content $W\left(\sigma_{m}\right)$ were converted into the values of static bending for a moisture content of $12 \%\left(\sigma_{m(12)}\right)$.

The strength and modulus of elasticity of the wood were determined while bending the wood using methods according to PN-EN 408:2004 and PN-77/D-04103 which were also used in the research of Fojutowski et al. (2010), Barański et al. (2014), Noskowiak et al. (2015) and Bieniasz et al. (2017).

The statistical analysis was conducted using STATISTICA 8 (StatSoft, Inc., USA).

\section{RESULTS AND DISCUSSION}

On the basis of the results of research conducted on the specimens it was possible to draw up a chart which presents the relationship between the specimen load and its displacement (Fig. 4). The section of the chart which corresponds to the load in the range from $0.1 F_{\max }$ to $0.4 F_{\max }$ was used in the regression analysis. For each chart the longest stretch of this section was identified, as it corresponded to the correlation coefficient equal to at least 0.99 . For the case in which the examined section contained a correlation coefficient at least in the range from $0.2 F_{\max }$ to $0.3 F_{\max }$, the calculations of the modulus of elasticity of the wood specimens from group A were performed through the application of Eqs (1) and (2) was applied to determine the same property for specimens from group B.

The results gained from the test were subjected to statistical testing. The comparison of the actual distribution of values resulting from the tests were derived through the application of a normal distribution and Wiebull distribution - a chi-square conformity test was used for this purpose. 


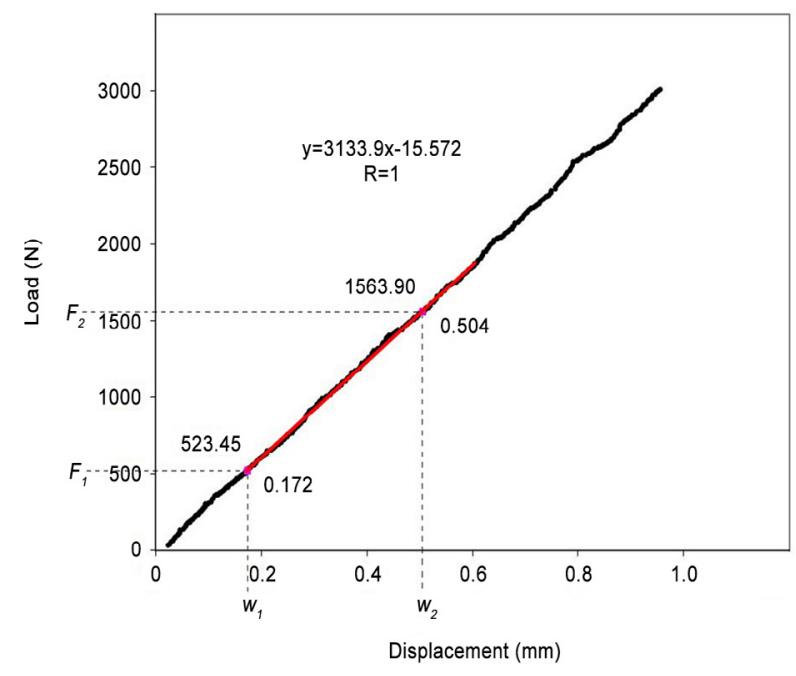

Fig. 4. Chart illustrating the relationship between the load $(F)$ and displacement $(w)$ in the area of plastic deformations.

Table 1. Summary of the results of the conformity of the distribution of the modulus of elasticity during static bending of wood specimens group A and B with the normal distribution (for the level $\mathrm{p}>0.05$ )

\begin{tabular}{lcc}
\hline Chi - square test & Group A & Group B \\
\hline Normal distribution & 0.909 & 0.272 \\
\hline
\end{tabular}

In the case of the analysis of the distributions of the modulus of elasticity of the wood tested under static bending for wood specimens group A and B a close conformity with the normal distribution is noted; however, the level of conformity is better for group A (Table 1).

Histograms and normality charts presenting the distributions of the modulus of elasticity also indicate the conformity of their results with the normal distribution; however, a lower correlation is indicated by the distribution of specimens in group B (Fig. 5).

Group B specimens indicate smaller variability ranges and lower values of the modulus of elasticity - the mean is 8911.4 MPa in comparison with group A specimens with a mean value of $14742 \mathrm{MPa}$ (Fig. 6). This results from the more regular structure and the elimination of the nonhomogenous macrostructure of group B wood specimens. Group A specimens must contain an admissible level of faults in order to classify them as premium class; hence, the presence of knot forms in them and the three levels of non-homogenous wood structure considerably affects the increase in the variability range of the modulus of elasticity. Earlier studies have shown that certain pine and spruce defects appear more often than others, and therefore have a more substantial impact on lowering round wood quality grades (Krotkievič, 1955 after Giefing, 1999; Taffe, 1955, after Giefing 1999).
As a result of the analysis of the distribution of wood specimens, which were subjected to a static bending strength test, using a chi-square test, it was indicated that the distribution of group A specimens indicates a better conformity with the Weibull distribution, while conformity with the normal distribution is better in the case of group B specimens (Table 2). Heydari et al. (2011) also conducted mechanical properties tests on walnut samples.

The results of the test also confirm the comparison in the distribution function, histograms presenting the distributions of groups A and B as well as probability charts, which contain a curve of empirical distribution as a function of the theoretical distribution function (Fig. 7).

In addition, as is the case for the modulus of elasticity, the differences in the variability of static bending strength for specimen groups A and B are sharply marked. However, in contrast to the analysis of the previous values, group A takes on a lower range of values - the mean is $54.2 \mathrm{MPa}$, while for group B - the mean is $98.4 \mathrm{MPa}$ (Fig. 8). This denotes a tendency towards a higher static bending strength of wood specimens with a more regular course of annual growth, which is accompanied by a higher level of order in the internal structure of wood without faults. The structure as well as the density of the wood are associated with the social position of the tree in the forest as well as with its age (Pazdrowski and Spława-Neyman, 1993; Giefing and Pazdrowski, 2012).

The statistical analysis described above indicates the characteristics of the distributions of the particular strength characteristics of the examined wood specimens in the particular groups. On the basis of the illustrated results of testing, one may note a tendency towards the conformity of these distributions of these characteristics with the normal distribution for the case of small wood specimens in group $\mathrm{B}$ and with the Weibull distribution for the case of larger specimens in group A. The mechanical properties were also evaluated by other specialists (Obidziński, 2012; SzyszlakBargłowicz et al., 2012).

The mechanical testing of wood properties includes the effect of wood anisotropy, which is due to the variable orientation of the tested wood elements and the direction of the loading applied in relation to the principal direction of wood anisotropy (Manrique et al., 1994; Mishnaevsky and Qing, 2008, Kyzioł and Czech, 2011). The anisotropy of plant tissue composed cells which are structural elements, is an element of its characteristics and has a substantial effect on its mechanical properties (Gancarz et al., 2014). Groups A and B of wood specimens were subjected to a fatigue strength test and the modulus of elasticity was established for each of the groups, in which case the direction of the force was perpendicular to the direction of the fibers. An analysis of the test results confirms the influence of the above assumptions. 

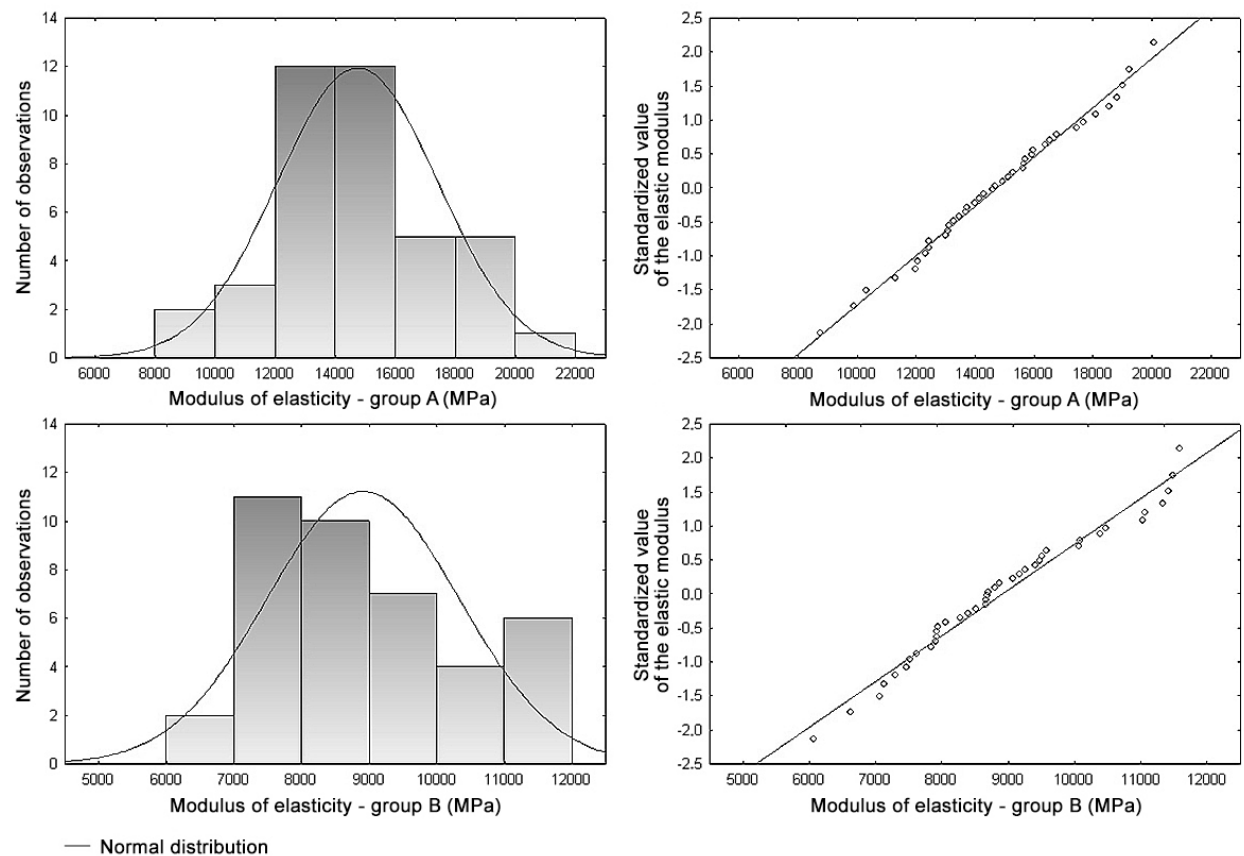

Fig. 5. Histograms presenting a comparison of the modulus of elasticity during static bending of wood and normal distribution and normality chart of groups A and B.

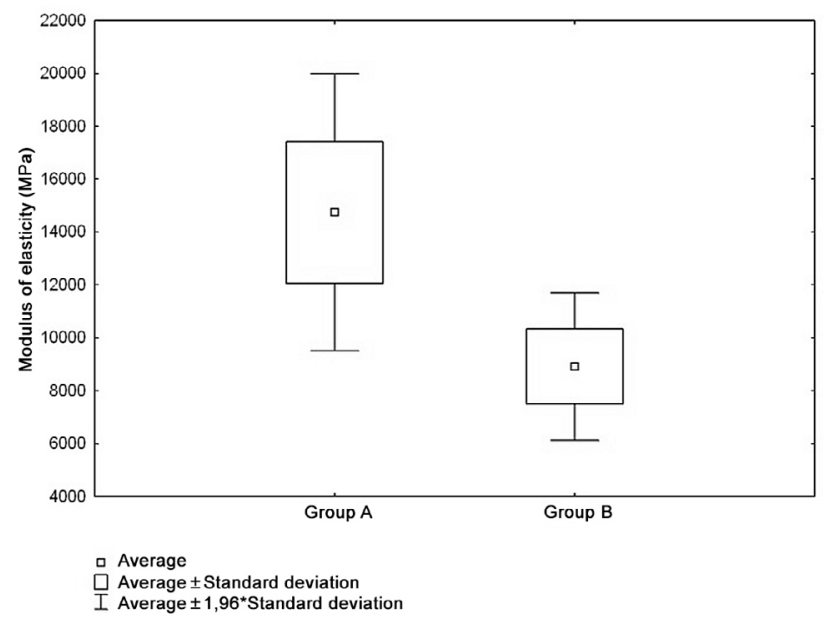

Fig. 6. Chart presenting the variability ranges of the modulus of elasticity during the static bending of wood specimens group A and $\mathrm{B}$.

Table 2. Comparison between the results of matching the distribution of static bending strength of group A and B wood specimens and normal distribution and Weibull distribution (for the level of $p>0.05$ )

\begin{tabular}{lcc}
\hline Chi - square test & Group A & Group B \\
\hline Normal distribution & 0.272 & 0.545 \\
Weibull distribution & 0.549 & 0.179 \\
\hline
\end{tabular}

The fatigue testing conducted indicates the occurrence of the scale effect when comparing particular specimen groups in connection with their dimensions and structure. This was also confirmed by previous studies (Lapka and Niesłony, 2014; Walczak et al., 2014).

Small wood specimens from group B were prepared in accordance with the standard in force, which meant that the structure had to be preserved at the macroscopic and microscopic level. This was also reflected in the analysis of the distributions and relevance of correlation between the specific properties noted in the specimen groups

Larger wood specimens from group A were similar to actual wood components in terms of their dimensions, which meant that neither non-homogeneity nor structural irregularity could be excluded in the specimens. Conformity between the static bending strength distribution and the Weibull distribution was established for this specimen group. The right-sided asymmetry in the distribution could be the effect of the influence of the wood parameters discussed above on its properties (Malaga-Toboła et al., 2017).

In the above analysis the phenomenon of the scale effect was illustrated as a result of comparing the actual smoothed distributions of specimen groups. The most striking illustration of this phenomenon could be noted during the comparison of the results of the static bending strength. For the case of bending - the distribution of group A specimens (non-homogenous ones) indicate a more narrow and smaller range of values in comparison with group B specimens. In addition, in this case we have to deal with a considerably larger difference with regard to specimen dimensions, and the surface of group A specimen cross 

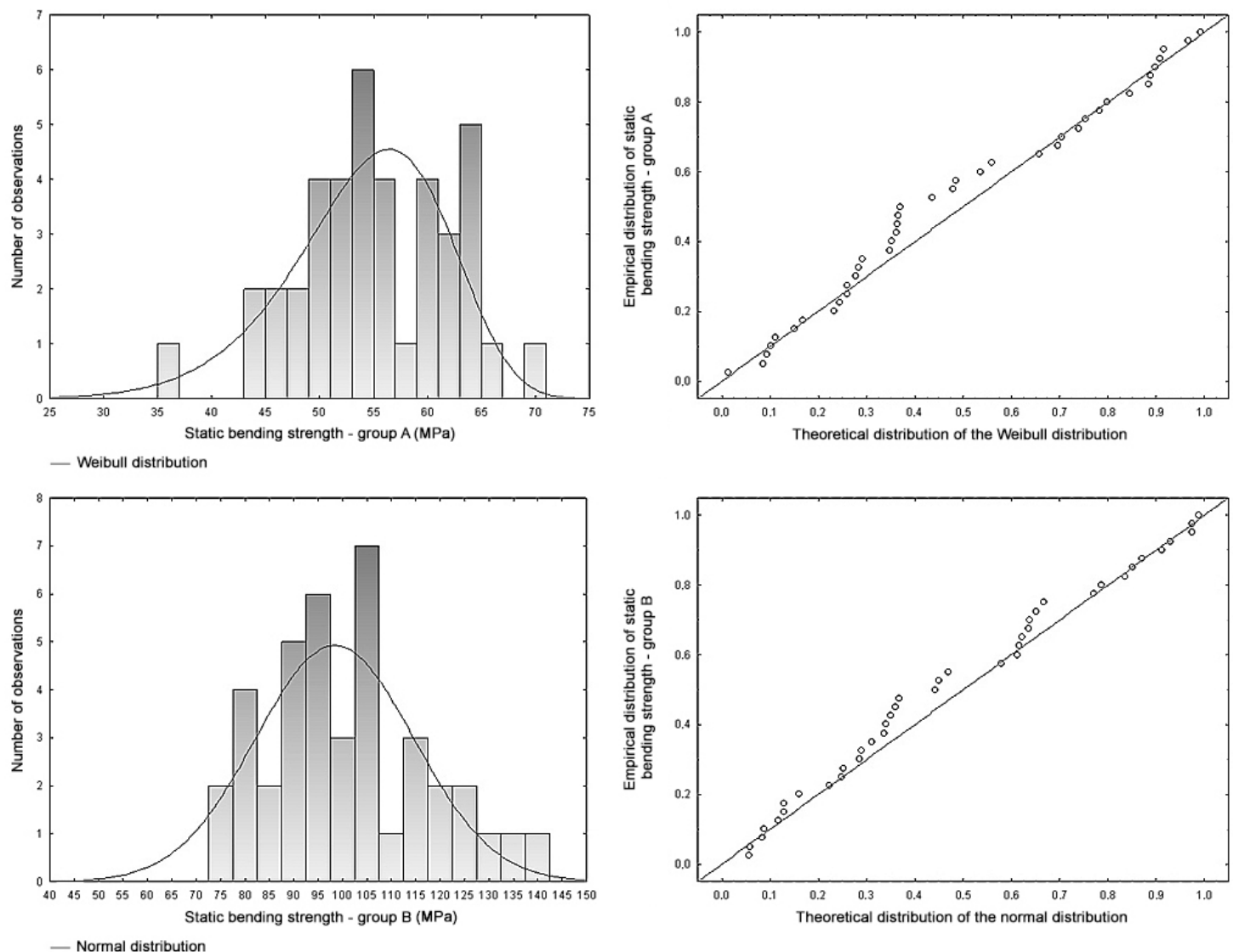

Fig. 7. Histograms illustrating a comparison between the static bending strength of wood and Weibull distribution (group A) and normal distribution (group B) and probability charts for groups A and B.

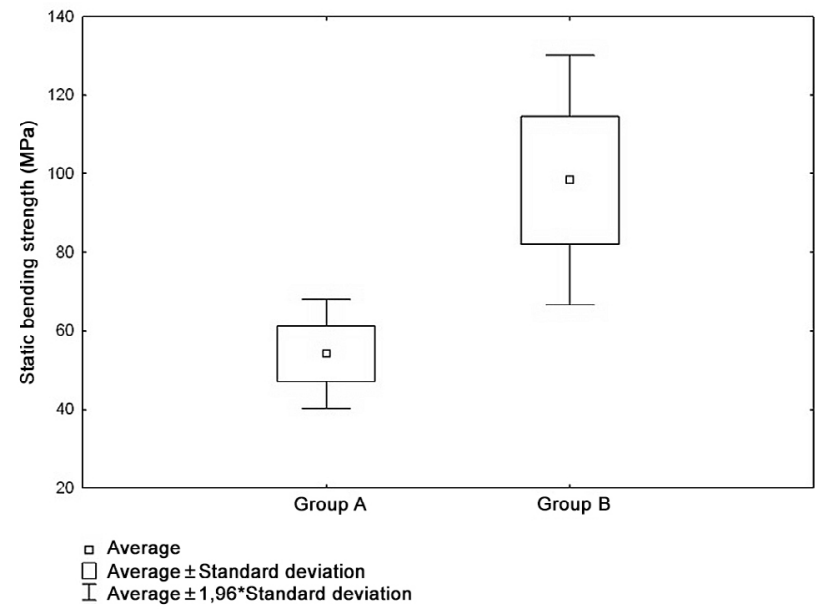

Fig. 8. Chart illustrating the variability ranges of the static bending strength in wood specimens group A and B.

section $\left(5320 \mathrm{~mm}^{2}\right)$ is thirteen times larger than the surface of specimen group B $\left(400 \mathrm{~mm}^{2}\right)$. Thus, in this case the dependence of the researched sample strength on inhomogeneity is visible which may be present at every level of its structure having a decisive influence on the value of the destructive force on the sample.

\section{CONCLUSIONS}

1. In contrast to isotropic bodies as well as homogeneous ones, the scale effect in wood is due to wood anisotropy, faults and a non-homogenous structure at the macroscopic level.

2. The effect of wood anisotropy on the elastic and fatigue characteristics of wood results from the orientation of the wood element and the direction of the load application in relation to the principal directions of anisotropy.

3. From the stochastic perspective, the higher the volume of the wood element, the higher the probability of the occurrence of changes in the natural element of the wood structure.

4. The effect of the natural wood faults and in particular gnarliness is particularly relevant in the case of the wood species, in which branching occurs annually in the form of rings (such as in pine wood which was the subject of the research reported here). Hence, the longer the wood samples, the higher the impact of the wood faults, on the properties of the samples and the greater the scale effect.

5. The scale effect differs depending on the method used for the determination of the mechanical strength of the wood in various directions of the load applied, which is a relevant aspect in the consideration of various engineering 
applications. This is due to various mechanisms affecting the principles of wood failure, which can be potentially explained on the basis of the knowledge of technical wood properties.

Conflict of interest: The Authors declare no conflict of interest

\section{REFERENCES}

Aguilera J.M., 2005. Why food microstructure? J. Food Eng., 67, 3-11.

Barański J., Chuchała D., Dzurenda L., Muziński T., and Orlowski K., 2013. Determination of moisture content profiles of spruce wood after high temperature process and air drying. Forestry and Wood Technology, 82, 49-56.

Barański J., Wierzbowski M., and Konopka A., 2014. The change of mechanical properties of selected wood species after drying process under various conditions. Forestry Wood Technol, 86, 13-17.

Bieniasz A., Lachowicz H., Buraczyk W., and Moskalik T., 2017. Technical quality of wood of 35 years old Norway spruce (Picea bies L.H. Karst) growing on experimental plot in the Rogów Forest Experimental Station. Sylwan, 161(10), 851-860.

Bodig J. and Jayne B., 1982. Mechanics of Wood and Wood Composites.Van Nostrand Reinhold Company, New York -Cincinnati-Toronto-London-Melbourne.

Chuchała D., Orlowski K., and Krzosek S., 2012. The effect of the late wood share upon density of the Polish pine wood as a function of its origin. Forestry and Wood Technol., 77, 118-124.

Fojutowski A., Noskowiak A., Kot M., Kropacz A., and Stangierska A., 2010. The assessment of mechanical properties of wood treated with ionic liquids. Drewno: prace naukowe, doniesienia, komunikaty, 53, 184, 21-37.

Gancarz M. and Konstankiewicz K., 2007. Changes of cellular structure of potato tuber parenchyma tissues during storage. Res. Agric. Eng., 53, (2), 75-78. https://doi. org/10.17221/2118-rae

Gancarz M., Konstankiewicz K., Pawlak K., and Zdunek A., 2007. Analysis of plant tissue images obtained by confocal tandem scanning reflected light microscope. Int. Agrophysics, 21, 1, 49-53.

Gancarz M., Konstankiewicz K., and Zgórska K., 2014. Cell orientation in potato tuber parenchyma tissue. Int. Agrophys., 28(1), 15-22. https://doi.org/10.2478/ intag-2013-0023

Giefing D.F., 1999. Pruning trees in the forest. Publishing house Agricultural University August Cieszkowski in Poznań, Poznań, Poland.

Giefing D.F. and Pazdrowski W., 2012. Deforestation and classification of roundwood. Publisher of the University of Life Sciences. Poznań, 130.

Heydari H., Jafari A., Mobli H., Rafee S., and Portahmasi K., 2011. Physical properties of walnut limbs. Int. Agrophys., $25,197-199$.

Kollman F.P., 1967. Verformung und Bruchgeschehen bei Holz als einen anisotropen, inhomogenen, porigen Festkörper. VDJ, 520, Berlin.

Korkut S. and Guller B., 2008. Physical and mechanical proper- ties of European Hophornbeam (Ostrya carpinifolia Scop.) wood. Bioresource Technol., 99(11), 4780-4785. https:// doi.org/10.1016/j.biortech.2007.09.058

Krotkievič P.G., 1955. Vyraščivanie vysokokačestvennoj drevesiny. Goslesbumizdat, Moskva Kyzioł L. and Czech M., 2011. Influence of the content of the polymer for anisotropy of the wood strength for tensile. Acta Mechanica et Automatica, 5, 1, 24-17.

Langrish T.A.G., Keey R.B., Kho P.C.S., and Walker J.C.F., 1993. Time-dependent flow in arrays of timber boards: Flow visualization, mass-transfer measurements and numerical simulation. Chemical Eng. Sci., 48 (12), 22112223. https://doi.org/10.1016/0009-2509(93)80238-1

Langrish T.A.G., Kho P.C.S., and Keey R.B., 1992. Experimental measurements and numerical simulation of local mass-transfer coefficients in timber kilns. Drying Technol., $\quad 10, \quad 753-781 . \quad \mathrm{https}: / /$ doi. org/10.1080/07373939208916474

Leontev N.L., 1970. Technique test wood. Ed. „Forest Indrusty “, Moscow, Russia.

Lionetto F. and Frigione M., 2009. Mechanical and natural durability properties of wood treated with a novel organic preservative/consolidant product. Materials Design, 30(8), 3303-3307. https://doi.org/10.1016/j.matdes.2008.12.010

Lapka M. and Niestony A., 2014. Scale effect in strength tests of non-homogeneous material on the example of wood. Zeszyty Naukowe, Mechanika, 103, 129-130.

Lapka M. and Sztyber J., 2007. Methodical aspects of pine wood strength testing on shear along fibers. Nationwide Scientific Conf. "Technology and technology in Polish forestry". A monograph issued on the occasion of the 50th anniversary of the Department of Forest Mechanization, 183, 52-56, SGGW Warsaw, Poland.

Madsen B., 1992. Structural Behaviour of Timber. Timber Engineering LTD, North Vancouver, Canada.

Malaga-Toboła U., Lapka M., Kurek M., Lukasiewicz M., and Kocira S., 2017. Wood modification methods. Przemysł Chemiczny, 7, DOI:10.15199/62.2017.7.24

Manrique E., Belenguer T., Dotta G., and Montoro T., 1994. Measurement of wood structural features by optical techniques. Int. Agrophysics, 8, 653-660.

Mareš V. and Blahovec J., 2004. Variation of the tree ring micro-hardness demonstrated on spruce wood. J. Forest Sci., 50(3): 135-141. https://doi.org/10.17221/4608-jfs

Miller R.B., 1999. Wood handbook - Wood as an engineering material. Forest Products Lab., Wisconsin, USA.

Mishnaevsky L. and Qing H., 2008. Micromechanical modeling of mechanical behavior and strength of wood: State - of the art review. Computational Materials Science, 44. https:// doi.org/10.1016/j.commatsci.2008.03.043

Moskaleva V.E., 1957. Structure of wood and its change in physical and mechanical effects. Ed. Acad. Science of the USSR, Moscow Ed. Acad. Science of the USSR, Moscow.

Niklas K.J., 1997. Mechanical properties of black locust (Robinia pseudoacacia L.) wood. Size and age-dependent variations in sap- and heartwood. Annals of Botany, 79, 265-272. https://doi.org/10.1006/anbo.1996.0340

Noskowiak A., Pajchrowski G., Szumiński G., and Jabłoński L., 2013. Technical characteristics of silver fir Wood (Abies alba Mill.) harvested in the Carpathian natural-forest region. Forestry Wood Technol., 83, 279-282. 
Noskowiak A., Pajchrowski G., Szumiński G., and Jabłoński L., 2014. Properties of Black polar wood (Populus nigra L.) in terms of structural applications. Forestry Wood Technol., 86, 189-192.

Noskowiak A., Pajchrowski G., Szumiński G., and Jabłoński L., 2015. Strength and modulus of elasticity of pine structural round timber. Forestry Wood Technol., 92, 300-306.

Obataya E. et al., 2006. Effects of high temperature kiln drying on the practical performances of Japanese cedar wood (Cryptomeria japonica) I: changes in hygroscopicity due to heating". J. Wood Sci., 52, 33-38, https://doi.org/10.1007/ s10086-005-0716-9

Obidziński S., 2012. Pelletization process of postproduction plant waste. Int. Agrophys., 26, 279-284. https://doi. org/10.2478/v10247-012-0040-8

Pang S., Simpson I.G., and Haslett A.N., 2001. Cooling and steam conditioning after high-temperature drying of Pinus radiate board: experimental investigation and mathematical modeling. Forestry Wood Technol., 35, Springer Verlag, 487-502. https://doi.org/10.1007/s00226-001-0124-2

Pazdrowski W. and Splawa-Neyman S., 1993. Research on selected properties of Scots pine (Pinus silvestris L.) wood against the background of biological classes in the stand. Folia Forestalia Polonica, Seria B, 24, 133-145.

Perelygin L.M., 1957. Drevesinovedenie. Izd. 'Lesnaja promyšlennost', Moskva.

PN-75/D-04123, 1975. Wood. Determination of the modulus of elasticity in static bending in the zone of pure bending.

PN-77/D-04103, 1977. Wood. Determination of static bending strength.

PN-EN 408:2004. Wooden constructions. Structural wood solid and glued in layers. Determination of some physical and mechanical properties (on full-size elements).

PN-82/D-94021, 1982. Coniferous construction timber sorted by strength methods.

PN-EN 13183-1:2004. Moisture of lumber art. Part 1: Determination of moisture by a drying-weight method.

PN-77/D-04101, 1977. Wood. Determination of density.

PN-63/D-04117, 1963. Physical and mechanical properties of wood. Determination of the elasticity coefficient for static bending.
Sándor P., et. al., 2006. Effect of high temperature treatment on the mechanical properties of birch (Betula papyrifera). Wood Sci. Technol., 40(8), 647-663, DOI: 10.1007/ s00226-006-0082-9

Sobolev Ju.S., 1979. Wood as a construction material. Ed. „Forest Indrusty “, USSR, Moscow.

Stasiak M., Molenda M., Gancarz M., Wiącek J., Parafiniuk P., and Lisowski A., 2018. Characterization of shear behaviour in consolidated granular biomass. Powder Technol., 327, 120-127. https://doi.org/10.1016/j.powtec.2017.12.037

Sun Z. F., Carrington C.G., and Bannister P., 2000. Dynamic modeling of the woodstack in a wood drying kiln. Chemical Eng. Res. Design, Chemical Eng. Res. Design, 78, 107-117. https://doi.org/10.1205/026387600526942

Szyszlak-Bargłowicz J., Zając G., and Piekarski W., 2012. Energy biomass characteristics of chosen plants. Int. Agrophys., 26, 175-179. https://doi.org/10.2478/ v10247-012-0025-7

Taffe W., 1955. Gütebewertung des Fichtenholzes verschiedener Standorte und Ertagsklassen in Rheinland-Pfalz. Hann. Münden, Germany.

Thibaut B., Gril J., and Fournier M., 2001. Mechanics of wood and trees: some new highlights for an old story. Acad Sci. Press, Paris, 329, 701-716.

Walczak A., Pieniak D., Oszust M., Blukacz M., and Ogrodnik P., 2014. Comparative study of the effect of scale in the modified wood compression test. Instytut NaukowoWydawniczy „SPATIUM”, 15, 5, 122-126.

Wierzbowski M., Barański J., and Stąsiek J., 2009. Gas-steam mixture wood drying”. COST E53 Meeting „Quality Control for Wood and Wood Products: EDG Drying Seminar „Improvement of Wood Drying Quality by Conventional and Advanced Drying Techniques", April 21-23, Bled, Slovenia, https://doi.org/10.1201/9780429463914-5

Zhong Y., Ren HQ., Lou WL., and Li XZ., 2012. The effect of knots on bending modulus of dimension lumber. 13th Int. Conf. Non - Conventional Materials and Technologies. September 22-24, 2011, Changsha, China. 